\title{
PENGARUH GAYA KEPEMIMPINAN DAN BUDAYA ORGANISASI TERHADAP PRODUKTIVITAS AGEN PT. (PERSERO) ASURANSI: PERAN MOTIVASI KERJA
}

\author{
Oleh : \\ Mulyadi $^{1}$, Sih Minarsih Hartati ${ }^{2}$, Siswoyo Haryono ${ }^{3}$ \\ ${ }^{1}$ Universitas Persada Indonesia-YAI, Jakarta \\ ${ }^{2,3}$ Universitas Muhammadiyah Yogyakarta
}

\begin{abstract}
Abstrak
Penelitian ini bertujuan untuk mengkaji pengaruh gaya kepemimpinan dan budaya organisasi terhadap motivasi kerja serta implikasinya pada produktivitas Agen PT (Persero) Asuransi Jiwasraya Wilayah Sumatera Selatan. Metode yang digunakan dalam penelitian ini adalah metode penelitian deskriptif dan survei. Penelitian ini dimaksudkan untuk membangun suatu gambaran sesungguhnya terhadap suatu fenomena yang berada dalam konteks penelitiannya. Dengan penelitian deskriptif ini akan dikumpulkan berbagai informasi dalam rangka pengujian hipotesis atau menjawab pertanyaan-pertanyaan yang menyangkut masalah penelitian. Model analisis menggunakan analisis SEM (Structural Equation Model). Penelitian dilaksanakan di Agen PT (Persero) Asuransi Jiwasraya Wilayah Sumatera Selatan. Hasil penelitian menunjukkan: (1) terdapat pengaruh gaya kepemimpinan terhadap motivasi kerja, (2) terdapat pengaruh budaya organisasi terhadap motivasi kerja, (3) terdapat pengaruh gaya kepemimpinan terhadap produktivitas, (4) tidak terdapat pengaruh budaya organisasi terhadap produktivitas, (5) terdapat pengaruh motivasi kerja terhadap produktivitas. Dalam penelitian ini disimpulkan juga bahwa budaya organisasi dapat mempengaruhi produktivitas dengan melalui motivasi kerja. Dengan demikian motivasi kerja merupakan variabel intervening yang baik untuk variabel budaya organisasi dalam mempengaruhi produktivitas.
\end{abstract}

Kata kunci : Gaya Kepemimpinan, Budaya Organisasi, Motivasi Kerja, Produktivitas

\section{PENDAHULUAN}

Asuransi Jiwasraya merupakan Persero dengan bidang usaha asuransi jiwa, dimana $100 \%$ saham dimiliki oleh Pemerintah Republik Indonesia berdasarkan Keputusan Menteri Keuangan RI Tanggal 28 Februari 1973 Nomor 84/MK/IV/2/1973. Sejarah panjang perusahaan membuat perusahaan ini matang dalam berkompetisi, sehat dan berpengalaman dalam bidang usahanya. Berdiri selama hampir 1,5 abad telah membuktikan kekuatannya sebagai perusahaan asuransi yang mampu memberikan perlindungan keuangan kepada para nasabahnya. Perkembangan demi perkembangan seiring dengan perubahan jaman terus terjadi. PT.

Pengaruh Gaya Kepemimpinan Dan Budaya Organisasi Terhadap Produktivitas

Agen PT. (Persero) Asuransi: Peran Motivasi Kerja (Mulyadi, Sih Minarsih Hartati, Siswoyo Haryono) 
(Persero) Asuransi Jiwasraya semakin mampu meningkatkan usahanya dengan tetap memberikan kualitas pelayanan yang semakin memuaskan kepada pemegang polis. Saat ini, tak kurang dari 2 juta nasabah telah mempercayakan masa depannya kepada PT. (Persero) Asuransi Jiwasraya. Kepercayaan ini selalu dipegang teguh dengan menjaga hubungan baik dengan nasabah, memberikan nasehat keuangan dan solusi yang tepat, serta mentaati standar kerja profesional. Dengan didukung sekitar 1.400 karyawan dan sekitar 8.000 agen yang tersebar di 17 cabang (Regional Office) di seluruh Indonesia. PT. (Persero) Asuransi Jiwasraya sepenuhnya sadar bahwa kebutuhan dan harapan pemegang polis atau nasabah pada dasarnya dapat terpenuhi dengan produk yang memenuhi kebutuhan, proses administrasi yang tepat waktu dan pelayanan yang ramah dan memuaskan. Tiga hal ini yang sudah, sedang dan akan terus dilakukan dan dikembangkan. Waktu telah membuktikan bahwa perusahaan telah melewati berbagai "periode" dengan baik, antara lain periode nasionalisasi, tranformasi, dan periode sekarang dimana perusahaan asuransi menjamur di negeri ini, PT. (Persero) Asuransi Jiwasraya yakin masih banyak periode-periode lain yang harus dihadapi di depan, dengan segala tantangan dan kompetisi. Dengan niat tulus membantu bangsa ini agar siap menghadapi masa depan, PT. (Persero) Asuransi Jiwasraya akan tetap berdiri tegak menciptakan produk dan memberikan pelayanan terbaik.

Pasar asuransi Indonesia yang masih besar, mengakibatkan persaingan semakin ketat. Banyak perusahaan asing yang ikut menikmati perkembangan industri asuransi Indonesia. Semua perusahaan berlomba-lomba menciptakan produk terbaik dan memberikan pelayanan seefektif dan seefisien mungkin. PT. (Persero) Asuransi Jiwasraya, sebagai satu-satunya perusahaan asuransi jiwa milik negara yang tidak memiliki hak monopoli, menggunakan momentum tumbuhnya asuransi ini dengan melakukan perubahan mendasar pada tahun 2003. Perusahaan tidak hanya merubah logo yang sudah menjadi citra perusahaan selama puluhan tahun, tapi juga meluncurkan Nilai-Nilai Inti yang menjadi budaya kerja baru setiap insan Jiwasraya agar perusahaan terus berkembang di tengah industri yang semakin kompetitif. Hal ini disadari dengan adanya pemikiran bahwa untuk mengejar target pasar asuransi Indonesia, PT. (Persero) Asuransi Jiwasraya masih menghadapi permasalahan mendasar, yaitu belum optimalnya produktivitas kerja agen. Kondisi belum optimalnya produktivitas agen PT. (Persero) Asuransi Jiwasraya Wilayah Sumatera Bagian Selatan, ditentukan oleh banyak faktor, diantaranya fungsi pekerjaan/kegiatan yang terkait dengan kinerja perusahaan, yaitu strategi perusahaan, pemasaran, operasional, sumber daya manusia, dan keuangan (Pabundu Tika, 2008). 
Terkait dengan sumber daya manusia sebagai salah satu sumber permasalahan yang mempengaruhi produktivitas, kepemimpinan adalah yang paling penting yang bisa menjadi pemberi solusi dalam sebuah organisasi. Menurut Robbins, (2010) kepemimpinan merupakan kemampuan untuk mempengaruhi kelompok menuju pencapaian sasaran. Organisasi membutuhkan kepemimpinan dan manajemen yang kuat untuk meraih efektivitas yang optimal. Hal ini sejalan dengan pendapat oleh Rezae (2010) yang menjelaskan bahwa kepemimpinan dapat membuat tenaga kerja terlibat dalam pengambilan keputusan, menjadi lebih terikat dan mengikuti pedoman yang ada tanpa menurunkan derajat pimpinan.

Cahyantara (2015) menyatakan bahwa gaya kepemimpinan dan budaya merupakan variabel yang perlu diperhatikan dalam meningkatkan produktivitas. Suryadi (2011) menjelaskan bahwa variabel motivasi kerja dan variabel budaya dapat mempengaruhi disiplin kerja, yang pada akhirnya secara bersama-sama akan meningkatan produktivitas kerja. Rusdiana (2011) dalam penelitiannya menjelaskan bahwa pengendalian mutu dan budaya kerja berpengaruh terhadap produktivitas kerja karyawan. Hal ini juga sejalan dengan pendapat Wijayanti (2011) yang menyatakan bahwa dalam usaha meningkatkan produktivitas pada suatu perusahaan, perlu adanya dukungan baik internal maupun eksternal dari karyawan.

Berdasarkan uraian-uraian teori-teori dari para ahli maupun kesimpulan dari beberapa penelitian terdahulu yang terpercaya, maka penulis tertarik untuk membuat penelitian yang mendalam tentang pengaruh gaya kepemimpinan, dan budaya organisasi terhadap motivasi kerja serta implikasinya pada produktivitas Agen PT (Persero) Asuransi Jiwasraya Wilayah Sumatera Selatan.

\section{LANDASAN TEORI DAN PENGEMBANGAN HIPOTESIS}

\section{Gaya Kepemimpinan}

Menurut Yukl (2013) istilah kepemimpinan merupakan kata yang diambil dari kata-kata yang umum dipakai dan digabungkan dari kata ilmiah yang tidak didefinisikan kembali secara tepat. Sebagian besar dari definisi mengenai kepemimpinan mencerminkan asumsi bahwa kepemimpinan berkaitan dengan proses yang disengaja dari seseorang untuk menekankan pengaruhnya yang kuat terhadap orang lain untuk membimbing, membuat struktur, memfasilitasi aktifitas hubungan di dalam kelompok atau organisasi. 
Menurut Robert House sebagaimana dikutip oleh Robbins (2016) mengungkapkan bahwa terdapat empat macam klasifikasi kepemimpinan yaknigaya kepemimpinan direktif, gaya kepemimpinan suportif, gaya kepemimpinan partisipatif, dan gaya kepemimpinan berorientasi pada tugas. Bermacam-macam gaya kepemimpinan dapat digunakan oleh seorang pemimpin untuk mempengaruhi dan memotivasi bawahannya, sehingga dapat meningkatkan kinerja bawahannya dalam melakukan pekerjaan.

Schein (2010) mengemukakan kepemimpinan adalah merupakan suatu pengaruh hubungan antara pimpinan dan pengikut yang bermaksud pada perubahan dan hasil nyata yang mencerminkan tujuan bersama. Sehingga kepemimpinan dapat disimpulkan sebagai sebuah hubungan yang saling mempengaruhi diantara pemimpin dan pengikut (bawahan) yang menginginkan perubahan nyata yang mencerminkan tujuan bersama.

\section{Budaya Organisasi}

Mulia (2011) menyatakan bahwa produktivitas juga dipengaruhi oleh budaya suatu organisasi, sumber daya yang berkualitas tidak akan memberikan hasil kerja yang optimal tanpa adanya budaya organisasi yang baik dan terinternalisasi oleh para anggotanya. Demikian pula sebaliknya jika budaya organisasi buruk akan memberikan hasil kerja yang tidak optimal.

Sedangkan Wirawan (2007) menyatakan budaya organisasi adalah norma, nilainilai, asumsi, kepercayaan, filsafat, kebiasaan organisasi, dan sebagainya yang dikembangkan dalam waktu yang lama oleh pendiri, pemimpin, dan anggota organisasi yang disosialisasikan dan diajarkan kepada anggota baru serta diterapkan dalam aktivitas organisasi sehingga mempengaruhi pola piker, sikap, dan perilaku anggota orgaisasi dalam melakukan pekerjaannya.

Robbins (2016) menyatakan bahwa budaya organisasi adalah persepsi bersama yang dianut oleh anggota suatu organisasi. Sedangkan Robbins (2004) mengemukakan sepuluh faktor yang merupakan dasar atau karakteristik dari suatu budaya organisasi, diantaranya: (1) inisiatif individual, (2) toleransi terhadap tindakan resiko, (3) pengarahan, (4) integrasi, (5) dukungan manajemen, (6) control, (7) identitas, (8) sistem imbalan, (9) toleransi terhadap konflik, dan (10) pola komunikasi. 


\section{Motivasi Kerja}

Menurut Robbins (2016) motivasi adalah proses dimana usaha seseorang diberi energy, diarahkan dan berkelanjutan menuju tercapainya suatu tujuan. Sedangkan menurut Frederick Herzberg dalam Priansa (2014) motivasi adalah faktor-faktor yang sifatnya ekstrinsik bersumber dari luar diri yang turut menentukan perilaku seseorang dalam kehidupan.

Mathias dan Jackson dalam Bangun (2012) motivasi adalah hasrat di dalam seseorang yang menyebabkan orang tersebut melakukan suatu tindakan dalam mencapai suatu tujuan. Kemudian menurut Heidjrahman (2011) mengemukakan bahwa motif merupakan suatu dorongan kebutuhan dalam diri pegawai yang perlu dipenuhi agar pegawai tersebut dapat menyesuaikan diri terhadap lingkungannya, sedangkan motivasi adalah kondisi yang menggerakan pegawai agar mampu mencapai tujuan dan motifnya.

Menurut Konopaske at. all (2012) motivasi adalah aksi kekuatan (forces acting) yang terdapat pada karyawan yang menyebabkan dan mengarahkan perilaku dalam bekerja. Colquitt at.all (2011) secara formal definisi motivasi adalah seperangkat kekuatan energi yang berasal dari dalam dan luar seorang karyawan menyebabkan berusaha untuk bekerja menentukan arah, intensitas dan ketangguhan bekerja. Namun dalam perkembangan terkini telah diyakini bahwa uang bukan satu-satunya alat motivasi pegawai yang ampuh. Uang sebagai faktor ekstrinsik memang penting, tapi ada faktor instrinsik lain yang jauh lebih penting.

\section{Produktivitas Kerja}

Ivancevich (2011) produktivitas memiliki dua dimensi yakni efektivitas dan efisiensi. Dimensi pertama berkaitan dengan pencapaian untuk kerja yang maksimal, dalam arti pencapaian target yang berkaitan dengan kualitas, kuantitas, dan waktu. Dimensi kedua berkaitan dengan upaya membandingkan masukan dengan realisasi penggunaannya atau bagaimana pekerjaan tersebut dilaksanakan. Produktivitas kerja dalam organisasi tergantung pada keefektifan kerjasama antara individu dan kelompok. Mathis (2011) produktivitas adalah ukuran dari kuantitas dan kualitas dari pekerjaan yang telah dikerjakan, dengan mempertimbangkan biaya sumber daya yang digunakan untuk mengerjakan pekerjaan. 
Mulia (2011) menyatakan bahwa produktivitas juga dipengaruhi oleh budaya suatu organisasi, sumber daya yang berkualitas tidak akan memberikan hasil kerja yang optimal tanpa adanya budaya organisasi yang baik dan terinternalisasi oleh para anggotanya. Demikian pula sebaliknya jika budaya organisasi buruk akan memberikan hasil kerja yang tidak optimal.

\section{Hipotesis Penelitian}

Cahyantara (2015) menyatakan bahwa gaya kepemimpinan dan budaya merupakan variabel yang perlu diperhatikan dalam meningkatkan produktivitas. Suryadi (2011) menjelaskan bahwa variabel motivasi kerja dan variabel budaya dapat mempengaruhi disiplin kerja, yang pada akhirnya secara bersama-sama akan meningkatan produktivitas kerja. Rusdiana (2011) dalam penelitiannya menjelaskan bahwa pengendalian mutu dan budaya kerja berpengaruh terhadap produktivitas kerja karyawan. Mulia (2011) menyatakan bahwa produktivitas juga dipengaruhi oleh budaya suatu organisasi, sumber daya yang berkualitas tidak akan memberikan hasil kerja yang optimal tanpa adanya budaya organisasi yang baik dan terinternalisasi oleh para anggotanya. Hal ini juga sejalan dengan pendapat Wijayanti (2011) yang menyatakan bahwa dalam usaha meningkatkan produktivitas pada suatu perusahaan, perlu adanya dukungan baik internal maupun eksternal dari karyawan.

Berdasarkan uraian dari pendapat para ahli serta penelitian terdahulu yang terpercaya serta konsep penelitian yang telah dikemukakan penulis di atas, maka hipotesis penelitian yang dikemukakan adalah sebagai berikut:

H1 : Terdapat pengaruh gaya kepemimpinan terhadap motivasi kerja

$\mathrm{H} 2$ : Terdapat pengaruh budaya organisasi terhadap motivasi kerja

H3 : Terdapat pengaruh gaya kepemimpinan terhadap produktivitas kerja

H4 : Terdapat pengaruh budaya organisasi terhadap produktivitas kerja

H5 : Terdapat pengaruh motivasi kerja terhadap produktivitas kerja

\section{METODE PENELITIAN}

\section{Populasi dan Sampel}

Populasi penelitian yang dimaksud disini adalah seluruh Agen PT (Persero) Asuransi Jiwasraya Wilayah Sumatera Selatan. Sedangkan sampel dalam penelitian ini adalah syarat jumlah sample yang harus dipenuhi jika menggunakan analisis 
Structural Equation Modeling (SEM), maka jumlah sample berkisar antara 100 - 200 atau minimal lima kali jumlah indikator. Haryono (2017). Berdasarkan pendapat di atas, dalam penelitian menggunakan 100 sample.

\section{Jenis dan Metode Pengumpulan Data}

Mengacu pada permasalahan dan tujuan penelitian, pendekatan penelitian ini adalah survey dengan pendekatan gabungan (mixed method) antara deskriptifkualitatis dan kuantitatif-inferensial. Analisis sebab akibat dalam penelitian ini untuk menyelidiki hubungan variabel terikat (endogen) dengan variabel-variabel bebas (exogen), sehingga hipotesis dapat teruji secara empirik melalui teknik statistik. Metode pengumpulan data dengan menggunakan kuesioner yang dibagikan kepada para responden yang kemudian diisikan jawaban. Jawaban dari responden kemudian di skor dengan menggunakan skala likert jawaban 1 s.d 5 .

\section{Teknik Analisis Data}

Teknik Analisa data yang digunakan dalam penelitian ini adalah analisis statistik deskriptif dan Partial Least Square (PLS) menggunakan program software SmartPLS 3.0. Tehnik analisis data deskriptif adalah statistik yang digunakan untuk menganalisa data dengan cara mendeskripsikan atau menggambarkan data yang telah terkumpul sebagaimana adanya tanpa bermaksud membuat kesimpulan yang berlaku umum atau generalisasi (Haryono, 2017). Metode analisis yang digunakan adalah Partial Least Square (PLS). PLS adalah salah satu teknik Structural Equation Modeling (SEM) yang mampu menganalisis variabel laten, variabel indikator dan kesalahan pengukuran secara langsung. Partial Least Square (PLS) merupakan metode analisis yang powerful oleh karena tidak mengasumsikan data harus dengan pengukuran skala tertentu, jumlah sampel kecil. PLS dapat membantu peneliti untuk mendapatkan nilai variabel laten untuk tujuan prediksi. Model formalnya mendefinisikan variabel laten adalah linear agregat dari indikator-indikatornya. Hasil estimasi dalam PLS dapat dikategorikan menjadi tiga, yaitu weight estimate yang digunakan untuk menciptakan skore variabel laten, estimasi jalur yang digunakan variabel laten dan antar variabel dan blok indikator, dan berkaitan means seta lokasi parameter (nilai konstanta regresi) untuk indikator dan variabel laten Imam Ghozali (2015). 


\section{HASIL DAN PEMBAHASAN}

\section{Validitas dan Reliabilitas}

Dalam penelitian ini pengujian instrumen dilakukan dengan uji validitas dan realiabilitas. Uji validitas dilakukan dengan melakukan (1) uji Convergent Validity, nilai yang diharapkan > 0,7. Namun menurut Chin, 1998 (dalam Ghozali, 2015) untuk penelitian tahap awal pengembangan skala pengukuran nilai loading 0,5 sampai dengan 0,6 dianggap cukup memadai. Dalam penelitian ini akan digunakan batas loading factor sebesar 0,50. (2) uji Discriminant Validity dengan cara membandingkan nilai loading pada variabel yang dituju harus lebih besar dibandingkan dengan nilai loading dengan variabel yang lain. (3) Average Variance Extracted (AVE), Nilai AVE yang diharapkan > 0,5. Uji Reliabilitas dalam penelitian dilakukan dengan menggunakan uji composite reliability, dikatakan reliabel apabila memiliki nilai composite reliability $\geq 0,7$. Uji validitas dan reliabilitas diolah menggunakan SmartPls 3.0.

\section{Pengujian Hipotesis}

Pengujian hipotesis dilakukan dengan menggunakan model Structural Equation Modeling dengan teknik Partial Least Squate untuk menguji pengaruh masing-masing variabel gaya kepemimpinan, budaya organisasi, motivasi kerja, dan produktivitas kerja. Selanjutnya pengujian hipotesis didasarkan pada tingkat signifikansi path coefficient yang didapat dari nilai $t$-statistic dan nilai standardized path coefficient. Batas nilai pengujian hipotesis yaitu nilai t muatan faktornya (loading factor) lebih besar dari nilai kritis $(>1,96)$. Hasil analisis dari model penelitian adalah sebagai berikut: 


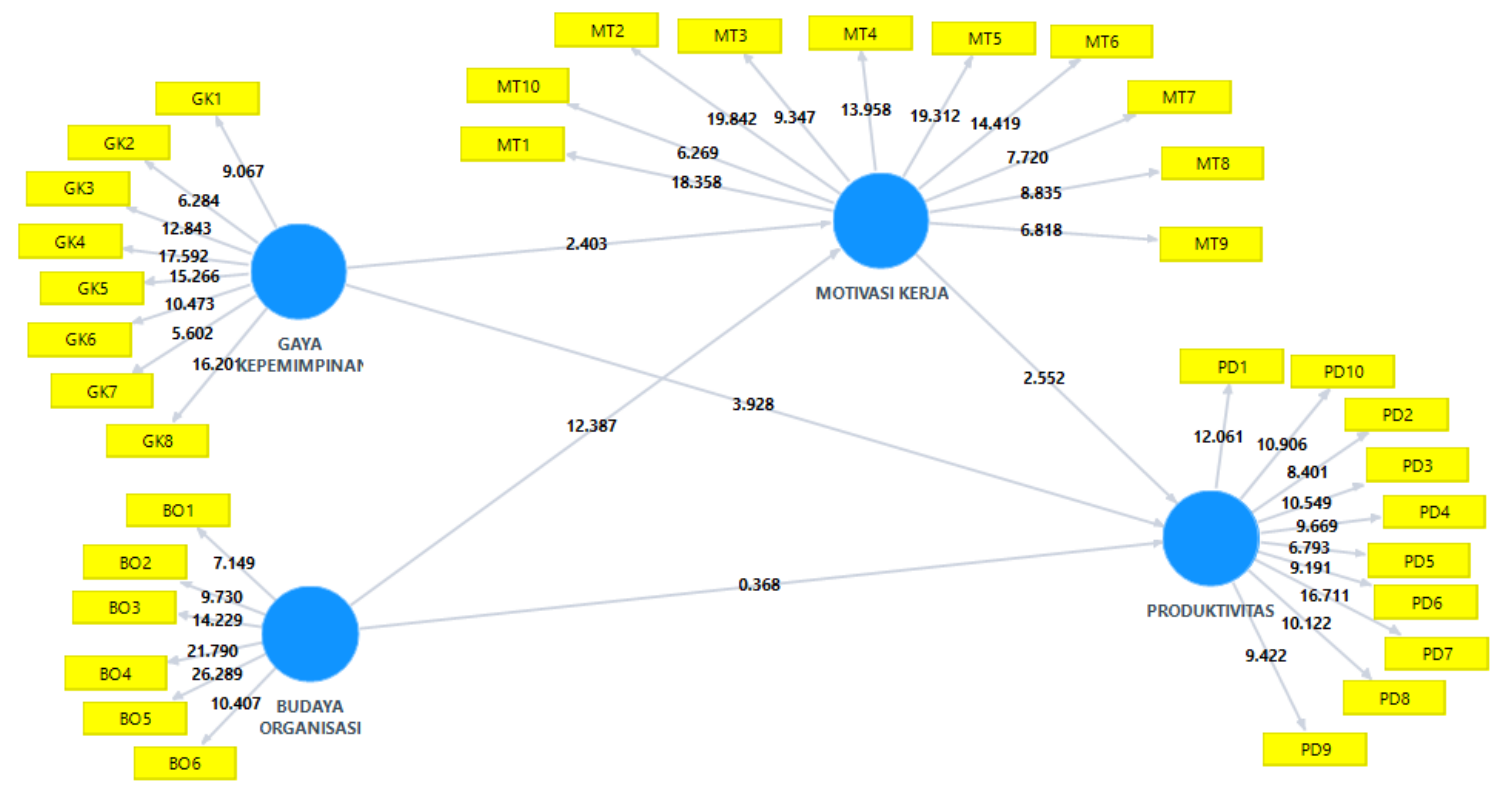

Gambar 1. Hasil analisis penelitian dengan PLS

Tabel 1. Hasil Pengujian Pengaruh Langsung

\begin{tabular}{|l|l|c|c|c|}
\hline No & \multicolumn{1}{|c|}{ Pengaruh Langsung } & $\begin{array}{c}\text { Nilai } \\
\text { Koefisien }\end{array}$ & T Hitung & P Value \\
\hline 1 & Gaya Kepemimpinan $\rightarrow$ Motivasi Kerja & 0.157 & 2.403 & 0.017 \\
\hline 2 & Budaya Organisasi $\rightarrow$ Motivasi Kerja & 0.762 & 12.387 & 0.000 \\
\hline 3 & Gaya Kepemimpinan $\rightarrow$ Produktivitas & 0.379 & 3.928 & 0.000 \\
\hline 4 & Budaya Organisasi $\rightarrow$ Produktivitas & -0.095 & 0.368 & 0.713 \\
\hline 5 & Motivasi Kerja $\rightarrow$ Produktivitas & 0.588 & 2.552 & 0.011 \\
\hline
\end{tabular}

Sumber: Output SmartPLS, diolah peneliti

Tabel 2. Hasil Pengujian Pengaruh Tidak Langsung

\begin{tabular}{|l|l|c|c|c|}
\hline No & \multicolumn{1}{|c|}{ Pengaruh Tidak Langsung } & $\begin{array}{c}\text { Nilai } \\
\text { Koefisien }\end{array}$ & T Hitung & P Value \\
\hline 1 & Gaya Kepemimpinan $\rightarrow$ Produktivitas & 0,092 & 1,904 & 0,057 \\
\hline 2 & Budaya Organisasi $\rightarrow$ Produktivitas & 0,448 & 2,276 & 0,023 \\
\hline
\end{tabular}

Sumber: Output SmartPLS, diolah peneliti

\section{Pembahasan}

Hasil pengujian hipotesis (H1) membuktikan bahwa terdapat pengaruh gaya kepemimpinan terhadap motivasi kerja. Diperoleh nilai koefisien $\mathrm{t}$ hitung sebesar $2.403>1.96$ dengan $p$-value $0,017<0.05$, atau berdasarkan koefisien pengaruh sebesar $0.157(15,7 \%)$ Pengujian ini secara statistik membuktikan bahwa gaya kepemimpinan berpengaruh positif terhadap motivasi kerja. Hasil penelitian ini sejalan dengan penelitian yang dilakukan oleh Amalia, dkk (2016) yang menyatakan 
bahwa gaya kepemimpinan berpengaruh signifikan terhadap motivasi kerja. Wowor dkk (2019) menyimpulkan bahwa gaya kepemimpinan berpengaruh positif signifikan terhadap motivasi kerja. Hasil Penelitian ini juga sejalan dengan Robert House sebagaimana dikutip oleh Robbins (2007) bermacam-macam gaya kepemimpinan dapat digunakan oleh seorang pemimpin untuk mempengaruhi dan memotivasi bawahannya, sehingga dapat meningkatkan kinerja bawahannya dalam melakukan pekerjaan.

Hasil pengujian hipotesis (H2) membuktikan bahwa terdapat pengaruh budaya organisasi terhadap motivasi kerja. Diperoleh nilai koefisien t hitung sebesar 12.387 > 1.96 dengan $p$-value $0,000<0.05$, atau berdasarkan koefisien pengaruh sebesar 0.762 $(76,2 \%)$ Pengujian ini secara statistik membuktikan bahwa budaya organisasi berpengaruh positif signifikan terhadap motivasi kerja. Hasil penelitian ini sejalan dengan penelitian yang dilakukan oleh Lawasa (2013) yang menyatakan bahwa budaya organisasi mampu mempengaruhi motivasi kerja. Ernanto (2015) menyatakan bahwa terdapat pengaruh yang signifikan budaya perusahaan terhadap motivasi kerja dari karyawan.

Hasil pengujian hipotesis (H3) membuktikan bahwa terdapat pengaruh gaya kepemimpinan terhadap produktivitas kerja. Diperoleh nilai koefisien t hitung sebesar $3.928>1.96$ dengan $p$-value $0,000<0.05$, atau berdasarkan koefisien pengaruh sebesar $0.379(37,9 \%)$ Pengujian ini secara statistik membuktikan bahwa gaya kepemimpinan berpengaruh positif signifikan terhadap produktivitas kerja. Hasil penelitian ini sejalan dengan penelitian yang dilakukan oleh Cahyantara (2015) menyatakan bahwa gaya kepemimpinan dan budaya merupakan variabel yang perlu diperhatikan dalam meningkatkan produktivitas. Hal ini sejalan dengan pendapat Robert House sebagaimana dikutip oleh Robbins (2007) mengungkapkan bahwa terdapat empat macam klasifikasi kepemimpinan yakni gaya kepemimpinan direktif, gaya kepemimpinan suportif, gaya kepemimpinan partisipatif, dan gaya kepemimpinan berorientasi pada tugas. Bermacam-macam gaya kepemimpinan tersebut dapat digunakan oleh seorang pemimpin untuk mempengaruhi dan memotivasi bawahannya, sehingga dapat meningkatkan kinerja bawahannya.

Hasil pengujian hipotesis (H4) menyatakan bahwa tidak terdapat pengaruh budaya organisasi terhadap produktivitas kerja. Hal ini berdasarkan nilai koefisien $t$ 
hitung sebesar $0.368<1.96$ dengan $p$-value $0,713>0.05$, atau berdasarkan koefisien pengaruh sebesar $-0.095(-9,5 \%)$ Pengujian ini secara statistik menyatakan bahwa budaya organisasi tidak berpengaruh terhadap produktivitas kerja. Hasil pengujian ini bertentangan dengan hipotesis dalam penelitian ini, namun hasil penelitian ini sejalan dengan pendapat oleh Siahaan (2013) yang menyatakan bahwa tidak terdapat pengaruh budaya organisasi terhadap produktivitas karyawan. Kemudian penelitian oleh Maabut (2016) menyatakan bahwa budaya organisasi berpengaruh negative tidak signifikan terhadap kinerja pegawai.

Hasil pengujian hipotesis (H5) membuktikan bahwa terdapat pengaruh motivasi kerja terhadap produktivitas kerja. Diperoleh nilai koefisien t hitung sebesar $2.552>$ 1.96 dengan $p$-value $0,011<0.05$, atau berdasarkan koefisien pengaruh sebesar 0.588 $(58,8 \%)$ Pengujian ini secara statistik membuktikan bahwa motivasi kerja berpengaruh positif signifikan terhadap produktivitas kerja. Hasil penelitian ini sejalan dengan penelitian yang dilakukan oleh Suryadi (2011) menjelaskan bahwa variabel motivasi kerja dan variabel budaya dapat mempengaruhi disiplin kerja, yang pada akhirnya secara bersama-sama akan meningkatan produktivitas kerja. Amelia (2016) menyatakan bahwa motivasi kerja berpengaruh terhadap kinerja karyawan.

\section{KESIMPULAN}

Berdasarkan hasil penelitian yang telah dijelaskan pada bab sebelumnya, maka dapat diperoleh kesimpulan bahwa: (1) gaya kepemimpinan berpengaruh positif terhadap motivasi kerja. Hasil penelitian ini sejalan dengan penelitian yang dilakukan oleh Amalia, dkk (2016), Wowor dkk (2019), dan Robbins (2007). (2) budaya organisasi berpengaruh positif signifikan terhadap motivasi kerja. Hasil penelitian ini sejalan dengan penelitian yang dilakukan oleh Lawasa (2013), dan Ernanto (2015). (3) gaya kepemimpinan berpengaruh positif signifikan terhadap produktivitas kerja. Hasil penelitian ini sejalan dengan penelitian yang dilakukan oleh Cahyantara (2015), dan Robbins (2007). (4) budaya organisasi tidak berpengaruh terhadap produktivitas kerja. Hasil pengujian dari penelitian bertentangan dengan hipotesis dalam penelitian ini, namun hasil penelitian ini sejalan dengan pendapat Siahaan (2013), dan Maabut (2016). (5) motivasi kerja berpengaruh positif signifikan terhadap produktivitas kerja. Hasil penelitian ini sejalan dengan penelitian yang dilakukan oleh Suryadi (2011), dan Amelia (2016). 


\section{DAFTAR PUSTAKA}

Amalia Rizqi Dzikrillah, Swasto Bambang, dan Susilo Heru, 2016. Pengaruh Gaya Kepemmimpinan terhadap Motivasi Kerja dan Kinerja Karyawan. (Studi Kasus pada Karyawan Pabrik Gula Kebon Agung Malang). Jurnal Administrasi Bisnis (JAB), Vol. 36, No. 1, Juli, hal. 137-146.

Bangun, Wilson, 2012. Manajemen Sumber Daya Manusia. Jakarta: Erlangga

Cahyantara Eka Agus Putu I, dan Subudi Made, 2015. Pengaruh Gaya Kepemimpinan

Partisipatif dan Budaya Kerja terhadap Disiplin Kerja Karyawan dan Produktivitas Kerja Karyawan pada PT. PLN (Persero) Distribusi bali, Area Bali Selatan. E-Jurnal Manajemen Unud, Vol. 4, No. 7, page: 2016-2035.

Christiani Nita Yuningsih, dan Rure Donatus Ananius, 2019. Pengaruh Likuiditas dan Free Cash Slow Terhadap Kebijakan Dividen dengan Good Corporate Governance Sebagai Variabel Intervening. Jurnal Among Makarti, Vol. 12, No. 24, hal. 49-69.

Colquitt, Jason A., Jeffery A. LePine, and Michael J. Wesson. 2011. Organizational Behavior. New York: McGraw-Hill.

Ernanto Bambang, Baga M Lukman, dan Sunarti Euis, 2015. Pengaruh Penerapan Budaya Perusahaan Terhadap Motivasi Kerja dan Kinerja Karyawan di PT. Rekayasa Industri. Jurnal Aplikasi Bisnis dan Manajemen (JABM), Vol. 1 No. 1, hal. 1-11

Ghozali, Imam. 2013. Aplikasi Analisis Multivariate dengan Program SPSS. Edisi Ketujuh. Semarang : Badan Penerbit Universitas Diponegoro.

Ghozali, Imam. and H. Latan, 2015. Partial Least Squares: Konsep, Teknik dan Aplikasi Menggunakan SmartPLS 3. 0, Edisi 2. Semarang: Universitas Diponegoro.

Haryono, Siswoyo, 2017. Metode SEM untuk Penelitian Manajemen dengan AMOS LISREL PLS. Jakarta: Luxima Metro Media.

Heidjrachman, Ranupandojo, 2011. Manajemen Personalia. Yogyakarta: BPFE Ivancevich, 2011. Perilaku dan Manajemen Organisasi. Edisi ke-7, Jakarta: Erlangga

Konopaske, 2012. Organizations: Behavior, Structure, Process, Fourteenth Edition. New York: McGraw-Hill

L. Mathis, Robert and H. Jackson, John, 2011. Human Resource Management (Edisi10), Jakarta: Salemba Empat.

Mulia, Sinta, 2011. Hubungan Budaya Organisasi dengan Produktivitas Kerja Karyawan. Jurnal Manajemen. Vol. 1, No. 1, Hal. 1-6

Pabundu Tika, 2008, Budaya Organisasi dan Peningkatan Kinerja Perusahaan, Jakarta, Bumi Aksara.

Priansa Junni Donni, 2014. Perencanaan dan Pengembangan SDM, Penerbit Bandung: Alfabeta

Rezaei, Dolatabadi and Safa, Muhammad, 2010. Effect of Directive and Participative Leadership Style on Employees' Commitment to Service Quality. International Bulletin of Business Administration, Vol. 9, Page: 31-42

Robbins, Stephen P \& Coulter, Mary. 2010. Manajemen. Edisi Kesepuluh. Jakarta: Erlangga.

Robbins, Stephen P, Timothy A. Judge, 2016. Perilaku Organisasi, Edisi 16, Jakarta: Salemba Empat. 
Rusdiana, Disa. 2011. Pengaruh Penerapan Gugus Kendali Mutu dan Budaya Kerja terhadap Produktivitas Kerja Karyawan (Studi Kasus: Departemen Produksi Rumah Potong Ayam PT. Sierad Produce, Tbk-Bogor). Jurnal Departemen Manajemen Fakultas Ekonomi dan Manajemen Institut Pertanian Bogor. Bogor.

Schein, Edgar H, 2010. Organizational Culture and Leadership, Jossey Bass, San Francisco

Siahaan Sarmauli, 2013. Pengaruh Pelatihan, Motivasi, Budaya Organisasi, dan Kepuasan Kerja terhadap Produktivitas Karyawan (Studi Kasus pada Karyawan Bagian Produksi PT. XYZ). Tesis, Program Pascasarjana Universitas Terbuka, Jakarta.

Suryadi, Edy A. 2011. Faktor Motivasi Kerja dan Budaya Kerja yang Mempengaruhi Kedisiplinan Kerja Dosen Pengampu Matakuliah Keperawatan Akademi Keperawatan Pamekasan. Tesis, Program Studi Magister Keperawatan Akper, Pemekasan.

Wijayanti, Emi. 2011. Rancangan Pengukuran Kinerja Pelayanan dengan Pendekatan Service Excelent Scorecard (Studi Kasus PT PLN (Persero) Wilayah Lampung Cabang Tanjung Karang). Program Sarjana Alih Jenis Manajemen Departemen Manajemen Fakultas Ekonomi dan Manajemen Institut Pertanian Bogor.

Wirawan, 2007. Budaya dan Iklim Organisasi - Teori Aplikasi dan Penelitian, Jakarta: Salemba Empat.

Wowor Qimberly Wulan, Sumayku Sontje M, dan Sambul A.P. Sofia, 2019. Pengaruh Gaya Kepemimpinan terhadap Motivasi Kerja Karyawan pada PT. Matahari Departement Store di MegaMall, Manado. Jurnal Administrasi Bisnis, Vol. 8, No. 2, Hal. 107-112.

Yukl, Gary. 2013. Leadership in Organizations. Penerbit: Pearson

Zebua, Martin, 2017. Pengaruh Gaya Kepemimpinan Terhadap Produktivitas Kerja Karyawan Pada PT. Coca Cola Cabang Malang. Jurnal Media Mahardhika, Vol. 15, No. 3. Hal. 295-304. 